\title{
Microbial Diversity: Relevance and Relationship Between Environmental Conservation And Human Health
}

\author{
Jeremias Pakulski Panizzon ${ }^{1,2}$, Harry Luiz Pilz Júnior ${ }^{1}$, Neiva Knaak ${ }^{1 *}$, Renata Cristina \\ $\operatorname{Ramos}^{2}$, Denize Righetto Ziegler ${ }^{2}$ and Lidia Mariana Fiuza ${ }^{1}$ \\ ${ }^{1}$ Laboratório de Microbiologia e Toxicologia; Universidade do Vale do Rio dos Sinos; São Leopoldo - RS - Brasil. \\ ${ }^{2}$ Projeto Escola de Alimentos do Instituto de Ciência, Tecnologia e Inovação em Alimentos; NUTRIFOR; São \\ Leopoldo - RS - Brasil.
}

\begin{abstract}
This work presents bibliographic data on the role and function of microbial diversity. The increasing use of probiotics and prebiotics foods has led to the studies on their actual functions in the human body. It is known that in the environment, microorganisms are extremely important in recycling of nutrients, balance of trophic chains, vital physiological activities in the plants and animals, as well as the conservation of natural habitats. In human food, these microscopic organisms contribute from flavoring products to the synthesis of antimicrobial substances and vitamins essential to living beings.
\end{abstract}

Key words: Bacteria, nutraceutical, collective health, review

\section{INTRODUCTION}

Environmental and health issues, along with the increase in food production, have been topics of investments in the area of scientific research. Food production with quality and quantity to meet the world's population is a matter related to public health. The defense of biodiversity stimulates the production of foods that provide benefits for the consumers and simultaneously benefit environmental sustainability.

Consumption of processed products with low nutritional value and high levels of trans fatty acids is frequent in the population. In Brazil, ten steps to a healthy diet were included in the National Plan for the promotion of proper nutrition and healthy weight, which aimed to improve people's knowledge about health and encourages the practice of physical exercises. In these ten steps, it is possible to check the improvement in the quality of life of the consumer, so they facilitate and improve the eating habits of the intestinal microbiota, and therefore, a person's health (Vinholes et al. 2009).

The human diet is a key indicator of quality of life and affects individuals in different ways, because of the importance of protein, vitamins, minerals and nutrients that are needed for the perfect functioning of the body. The cereals have similar percentages of protein, lipid, fiber, ash and carbohydrate. Cereals are foods of plant origin, consisting of grains and largely consumed by the people worldwide. The name 'cereal' derives from the Ceres, the Greek goddess of agriculture and harvest. The main cultivated cereals are rice, wheat, corn, oats, rye, barley and triticale. They are widely consumed for being part of the food habits of many people; for ease of culture, conservation, transportation and income, for being

*Author for correspondence: neivaknaak@gmail.com 
low cost and good nutritional value and for the great variety of forms of use (Coppens 2005).

Rice is one of the most cultivated cereals in the world for human consumption and raw material for the food industry. There are increasing trends of these industries to seek rice, mainly organic and whole grain rice, due to health issues and the media, which has an interest in the cultural revival of a power based on wholegrain products (Ley et al. 2005). Rice, despite not being a food rich in vitamins, has a differential to be easily assimilated by the body. Its main component is starch, which provides energy, serving as fuel for the functioning of the body. The protein percentage varies around 3 to $12 \%$ depending on the type of rice (Ibge 2013).

Practitioners of macrobiotic and vegetarian diets seek to use rationally, using the rice in order to promote a complementary action of one food over another. In nature, the microbial communities facilitate the flow of nutrients and energy from the earth, but little is known about the interaction, and their diversity is still underestimated. Their patterns of succession and how their spatial distribution also occurs are poorly studied (Barbosa et al. 2010). Therefore, functional biodiversity in agroecosystems is key to the ecological sustainability of production and microorganisms are essential to this process (Johnson et al. 2003).

Bacteria comprise a large microbial community, consisting of species considered pathogenic to humans, animals and plants, or even beneficial species that interact with other organisms. Therefore, the importance of the study of microbial diversity is at stake.

\section{METHODS}

The bibliographic search was performed through a systematic search covering the 1900s and up to 2013. The terms "soil bacteria", "agroecosystem" and "nutraceutical" were utilized to search databases like SciELO and Portal Capes. These databases fulfill the minimum criteria search to conduct a systematic review, in accordance with the literature. The articles written in languages other than English, Spanish or Portuguese were excluded. Then the full text of selected articles and cited references were analyzed, which were selected in additional studies that belonged to the subject. The initial search identified 68 articles, which were used for the preparation of this review article

\section{MICROBIAL DIVERSITY \\ In preserved ecosystems}

Microorganisms represent the richest repertoire in chemistry and molecular diversity in nature, providing the basis for ecological processes such as biogeochemical cycles and food chains, as well as maintaining vital relationships among themselves and with superior organisms (HunterCevera 1998). The diversity of microorganisms is as vast as it is unknown. So far, between 0.1 and $10 \%$ of microbial species are known, depending on the habitat studied. In an agroecosystem, the variation in microbial diversity throughout the seasons is still not well understood, since in each season, one microbial community seems to occur more dominantly, accompanied by other less abundant that often are below the level of detection using the current methods of evaluation (Torsvik and Ovreas 2002). The diversity of microorganisms is critical to the functioning of the ecosystem, because there is the need to maintain ecological processes such as decomposition of organic matter, nutrient cycling, soil aggregation and controlling pathogens within the ecosystem (Kennedy 1999). The functional diversity is very important in ecological assessments of microorganisms within the ecosystem, mainly because little is known about the relationship between the structural and functional diversity of these microorganisms. There is, however, a consensus that microbial diversity is directly related to ecosystem stability (Yamanaka et al. 2003).

\section{In agroecosystems}

Modern agriculture is characterized by a constant search for increased crop yields through the use of mechanization, irrigation, chemical fertilization and pesticide application, coupled with the improvement of plant genotypes. However, the environmental impact caused by the intensification of farming did not always receive the necessary attention. The lack of detailed knowledge about the ecosystem and/or inadequate planning for land use led to a framework of intense environmental degradation, with loss of non-renewable resources and biodiversity not only in Brazil but in other countries (Eussen 1997). The observation in the increase of degraded agricultural areas has led to a change in the concept of land use, based on a 
holistic view of the agricultural process, where natural resources (soil, water and biodiversity) are exploited more sustainably.

The diversity of microorganisms as an indicator of the quality of agroecosystems has been widely debated, especially in the last decade, with the advent of molecular biology techniques that have favored the evaluation of microorganisms in environmental samples (Coutinho et al. 1999; Tiedje et al. 2001; Unicomb et al. 2005). The main argument in favor of such environmental feature is the fact that the microbial diversity naturally remains unchanged throughout the year (Dickens and Anderson 2001). Despite the continued use of land for agricultural practices, the soil may be rich in the biological point of view, since many microorganisms found in this environment are considered important in the biological control of diseases and pests of agriculture (Andreoti 2009). Thus, microbial processes play a fundamental importance in the functioning of production systems, performing tasks directly related to their productivity and sustainability (Boncowski and Roy 2005).

Rice is a plant of the genus Oryza of the grass family. $O$. sativa (Asian rice) and $O$. glaberima (African rice) are the two most cultivated species. The domestication of rice happened about 10,000 years ago in Asia. In Brazil, the plant was introduced by the Portuguese (Heinrichs 1997; Hunter-Cevera 1998). Rice is still considered the main component of the world's staple diet, although the per capita consumption in Brazil has decreased by $40.5 \%$, according to the study by the Brazilian Institute of Geography and Statistics (FAO) in 2013. However, it is noteworthy that the production of rice in 2013 was 12,816 million tons. Rice cultivation in Brazil is primarily in irrigated mode. The largest producing state of Brazil is Rio Grande do Sul with 1,0666 million hectares, representing $44.5 \%$ of the national area and accounting for $66.5 \%$ of Brazilian production (Panizzon et al. 2013).

Microbiological monitoring of water and soil depends on the quality of water entering the crops. Part of the diversity of Gram-positive bacteria found in rice ecosystems belong to the groups Bacillus, Micrococcus, Staphylococcus, Corynebacterium and Lactobacillus, along with a variety of Gram-negative species belonging to the families Enterobacteriaceae, and Peseudomonadaceae Aeromonadaceae, Vibrionaceae, Brucellaceae, Burkholderiaceae,
Xanthomonadaceae and others (Reche and Fiuza 2005). Among the Gram-negative bacteria, the following species have been identified by the same authors in rice cultivation waters: Escherichia coli, Enterobacter sp. Citrobacter freundii, Klebsiella pneumoniae, K. oxytoca, Proteus mirabilis, $P$. vulgaris, $P$. penneri, Citrobacter spp, Enterobacter cloaceae, Providencia rettgeri, Stenotrophomonas maltophilia, Ochrobactrum anthropi, Chromobacterium violaceum, Yersinia enterocolitica, Pseudomonas aeruginosa, $P$. fluorescens and Burkolderia cepacia.

\section{In Human microbiota}

The human body is populated by a large number of microorganisms, being distributed in various tissues and organs. It is believed that the abundance of microorganisms is greater than the number of cells in the body and is directly related to the immune system and better utilization of feed (Brandt et al. 2006). The digestive system consists of the alimentary tract associated with organs that partially perform digestion, mechanically and chemically. The purpose of the digestive system is the breakdown of food into smaller particles in order to be absorbed in human body.

The gastrointestinal tract of mammals maintains a highly diverse microbial population that plays an important role in nutrition metabolism, protection against pathogens, and the development of the immune system. It is estimated that at least 1000 different bacterial species coexist the human intestinal tract. Although often considered as pathogens, the majority of microorganisms in intestinal tract have beneficial effects. They play multiple roles in the human host, as they are directly involved in the synthesis of vitamins and cofactors, help to degrade complex lipids and polysaccharides and also have detoxifying action (Kennedy 1999; Douglas- Escobar et al. 2006). It is known that bacteria intensely populate the most part of the enteric tract. However, the stomach and the small intestine have fewer microorganisms due to the presence of hydrochloric acid (Bedani et al. 2009). The large intestine has numerous bacteria, especially Lactobacillus sp., Escherichia coli, Klebsiella sp. and Proteus sp. that assist in the synthesis of degradation of the food (Camargo et al. 2011; Odonkor and Ampofo 2013).

The intestinal microbiota is a dynamic mixture of microorganisms, whose composition varies along the gastrointestinal tract (GIT) and between the 
mucosa and the intestinal lumen. The microbiota develops all the time, due to the interaction of genetic factors, contact with the environment, diet and disease, thus explaining the fact that each individual presents a unique microbiota (Bedani et al. 2009).The genotype of the individual may also be a factor that influences the bacterial community in the gut, following a hypothesis that in the gut there are sites of specific adhesion to some bacteria in the host, selecting the most important. These adhesion sites are probably genetically predetermined (Brandt et al. 2006). Figure 1 represents didactically the factors that can influence the intestinal microbiota.

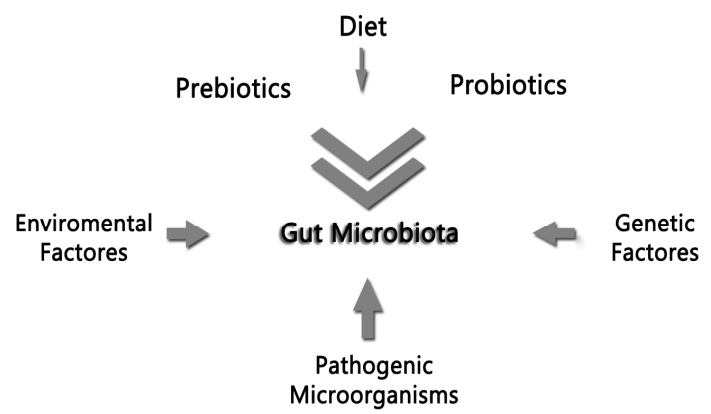

Figure 1 - Factors influencing the bacterial community in the human gut.

The highest concentration of microorganisms and metabolic activity is found in the large intestine. Starting from the ileum the concentration of bacteria increases gradually, reaching $10^{11}$ to $10^{12}$ $\mathrm{CFU} / \mathrm{g}$ in the colon. The adult and stable microbiota are composed of autochthonous species (permanent members) and allochthonous (transient members that are acquired from an external source). The microbiota are diverse, comprising 400-1000 species, of which over 60\% are not cultivable outside the intestine (Moreira 2012). The intestinal microbiota plays different roles that are important for the host such as they exert a trophic effect on the intestinal epithelium, favoring the development of microvilli, which in turn promotes the absorption of the nutrients (Moreira 2012). The diet is a major determinant for the persistence of certain bacteria in the gastrointestinal tract, because the diet provides nutrients, not only for the host, but also for bacteria that are in it. Components from indigestible food serve as carbon and energy source for the human gut bacteria (Blaut and Clavel 2007).

The intestinal biota is increasingly considered a symbiotic partner for the maintenance of health. Over the years, the intestinal microbiota has become recognized in the development of the immune system. The cells of the intestinal mucosa and microbiota (enterocyctes, dendritic cells, lymphocytes, macrophages) regulate the production of several cytokines and chemokines). The homeostasis of the intestinal tract is dependent on characteristics of the host (age, gender, genetics, etc) and environmental conditions (stress, drugs, gastrointestinal surgery, infectious and toxic agents). Changes in the gut microorganisms can be reversed by diet and weight loss. Qualitative and quantitative changes in the consumption of specific food components (fatty acids, carbohydrates, micronutrients) have effects not only on the composition of intestinal microbiota, but can modulate the expression of genes in the host tissues such as the liver, adipose tissue, intestine, and muscle. This in turn can lead to the development or decrease of fat mass and metabolic disorders associated with the intestinal barrier and systemic immunity. These intestinal microbiota are composed of various bacterial groups. Therefore, it is essential to keep them balanced to preserve human health.

Some bacteria have been used as a probiotic, such as species of the genera Lactobacillus and Bifidobacterium, which help in the restoration of the human intestinal microbiota, when the intestinal biota is drastically reduced and is vulnerable to attack by the pathogens (Santos and Cançado 2009).

\section{Human nutraceutical}

The evolution of nutritional science made it possible to know a little more about the food composition and action of these substances in the body. Studies have been carried out on the phytochemical constituents of the nutraceuticals in the food in order to study their health benefits. Nutraceuticals are dietary supplements that contain a concentrated bioactive compound in the food. They are used for improving the health that could be obtained from the food (Zeisel 1999).

The Brazilian Health Surveillance Agency of the Ministry of Health in the ordinance $n^{\circ} 398$, April 30, 1999 defined the functional food as the ingredient that claimed functional or health properties. It may, in addition to basic nutritional 
functions, in the case of a nutrient, and produce metabolic or physiological effects and or health benefits, and should be safe for consumption without medical supervision (Vigilância Sanitária 1999). The importance of the adequacy of food with respect to microorganisms in order to reduce the cost, increase quality regarding the taste and nutrition must be kept in mind. They produce a more flavorful food, with less cost and less waste of chemicals, which is of great significance for the food industry (Ley et al. 2005; Panizzon et al. 2012).

\section{Prebiotic and probiotic microorganism}

The gastrointestinal tract is colonized by the microorganisms soon after the birth of the individual and also after certain life situations, such as the consumption of antibiotics, resulting in the reduction of microorganisms in the gut, which makes it important to understand when this type of food should be used.

The enterobacteria and some species of Clostridium spp. are harmful to human health. The gut biota balance is maintained by the interrelations between the bacteria themselves and the host. Accordingly, the probiotics increase the number of microorganisms in the host; in addition, they induce pro-inflammatory, anti-inflammatory and anti-carcinogenic actions. The majority of probiotic microorganisms are lactic acid bacteria, which are Gram-positive and microaerophilic (Rodrigues and Barroso 2011). Probiotics are dietary supplements added to the food in adequate quantities influencing their nutritional and therapeutic value. They are represented by cultures of live microorganisms (beneficial bacteria and yeasts), which contribute to improve the flavor of the final product and produce antimicrobial substances (Santos 2009). Prebiotics are food ingredients that are primarily substrates for the growth of the intestinal microorganisms, not digested in the small intestine that, upon reaching the large intestine, are selectively metabolized by a limited number of bacteria, called beneficial, which alter the microbiota of the colon generating a healthy bacterial microbiota (Raizel et al. 2011). A healthy diet by adding probiotics and prebiotics in food benefits the people. In today's society, with the increasing population life expectancy and drug costs, nutraceutical should unify scientific knowledge about the public health and nutrition suitable to these new challenges by promoting health and not just curing diseases. The healthy microbiota promotes well-being and with the addition of probiotics, it is possible that they could produce antagonistic effects against unwanted microorganisms. Therefore, knowledge of the gut biota leads to the development of numerous public health strategies (Saad 2006). The importance of probiotic approach to the management of obesity in humans is supported by some intervention studies in humans so far, but the experimental data obtained with the compounds help to elucidate potential new molecular targets associated with the diet and the existing bacteria (Delzenne et al. 2011).

Recent studies involving rice bran and its oil have shown that they possess prebiotic potential, aiding in the growth of important microorganisms in the intestine, such as those of the genus Lactobacillus that are highly effective in controlling the intestinal infections by Salmonella and are catalysts of non-digestible molecules (Kumar et al. 2012; Tamura et al. 2012). Changes in the bacterial composition of obese versus lean people relate to bacterial phyla such as, for example, a reduction in Bifidobacterium spp. or an increase of Staphylococcus aureus (Neyrink and Delzenne 2010).

\section{Pathogenic microorganisms}

The members of the normal microbiota can cause diseases under certain circumstances. Since they have a non-invasive way of life defined by limitations of the medium, unless they are held they can become pathogenic. Population levels of microorganisms are determined by the exogenous and endogenous multifactorial processes (Griffiths 2001).The bacteria of the intestinal tract have heterogeneous distribution. The colonization of the intestinal tract depends on the ability of bacterial adhesion. There are bacteria on the adhesion sites on the intestinal mucosa, which need not to be periodically reintroduced. However, there is the native biota that is external to the gut ecosystem, thus is transient. The microbiota has the following functions: antibacterial, immunomodulatory and metabolic. Antibacterial prevents the establishment of pathogenic bacteria. Immunomodulatory activity helps the immune system and metabolic function contributes to facilitate the nutrition (Brandt et al. 2006). It is important to highlight the impact that pathogenic bacteria can cause in the public health issue, resulting serious intestinal diseases such as diarrhea - considered as the most common disease 
caused by viruses and bacteria and one of the diseases that affects large no of children in the world. Hence, it is important to know the bacteria that may possibly compromise the gut and the human organism as a whole (Clotildes 2007). The use of antibiotics in the rats can increase intestinal microbiota associating to some changes that affect the acquisition of energy from compounds in the diet and how it is spent and stored (Ley et al. 2005).Salmonella is represented by more than 40 serogroups and 2000 serotypes and may be classified as typhoid and non-typhoid. This genre is usually associated with food. Salmonella enteritidis (Fig. 2B) is one of the serotypes most widely distributed in the world and one of the major contaminants in food, usually beef, pork, poultry and eggs. This bacterium usually causes fever, abdominal cramps and diarrhea, which can present blood clots. A study by the Center for Epidemiological Surveillance - SES / SP showed that from 1999 to 2007, S. enteritidis was responsible for $42.3 \%$ of outbreaks of diarrhea, showing the attention in public health that this bacterium should be given (Kirk et al. 2004; Unicomb et al. 2005; Paiao et al. 2013).

Escherichia coli (EPEC) (Fig. 2C) causes gastroenteritis in almost all age groups. It is similar to Shigella sp (Fig. 2D) because it penetrates directly into the intestinal epithelium where it can multiply, causing dysentery. It can be transmitted by the consumption of water and many foods such as milk and milk products. The importance of EPEC as a cause of diarrhea has declined since the $1960 \mathrm{~s}$, but is the primary infectious agent in children in developing countries, including South America, Africa and Asia. EPEC outbreaks are sporadic, emerging in places where sanitary conditions are poor (Silva et al. 2001; Maltick et al. 2010). Other bacteria that are not involved directly with the human gut, but are cause of worry in the matter of public health, are related to urogenital infections, such as Proteus vulgaris (Fig 2A), which inhabits the human gut, but causes urinary tract infections and other complications (Rodrigues and Barroso 2011).

Having a prebiotic diet can help treating the intestine infections, such as those caused by the bacteria of the genus Salmonella because these prebiotic molecules serve as substrate for the growth of bacteria, which has the potential to eradicate other pathogenic bacteria such as Lactobacillus (Kumar et al. 2012).

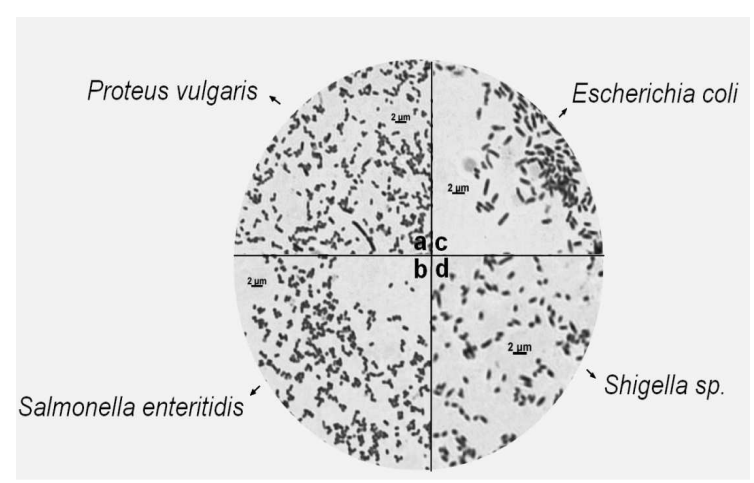

Figure 2 - Photomicrographs of bacteria (100x) for representing their morphology.

Microbial diseases of the large intestine are second only to the respiratory system diseases. Pathogens are able to cross the digestive system and extend to organs, causing numerous diseases, e.g., gastroenteritis caused by Salmonella and rotavirus. Bacillus cereus is common in the soils and vegetables. Rice has vast abundance of this bacterium. It is generally harmless, but when found in the foods, can cause illnesses such as gastroenteritis. The rice, for being a plant that is cultivated in water, has the risk of receiving numerous microorganisms. Water is characterized by low nutrients. Therefore, bacteria tend to grow on standing surfaces in particular materials, as is the case with rice (Pomeroy 1974a; Pomeroy et al. 2007b; Andreoti et al. 2009). Therefore, paddy fields are important for local biodiversity conservation because they support a rich biodiversity and high productivity feature. Rice is one of the most important cereal crops in the world. Therefore, the conservation of biodiversity in agriculture is a challenge of great importance. Several studies have demonstrated the contribution of ecosystems such as rice, providing habitats for creation of numerous microorganisms (Hofman et al. 2003; Maltick et al. 2010).

The microorganisms in the biosphere perform important functions, for example, the influence on biogeochemical processes. In aquatic environments, there is an important chain of interactions that affect the elements involved in the environment (Comte et al. 2006). It is noteworthy that quality evaluations in health should always aim at the welfare of the patient, which is always the focus of the studies. Therefore, monitoring allows detecting the faults and correcting them in 
order to not compromise the product and the consumer (Abrantes et al. 2007).

It is possible to relate the bacteria of rice with their intake and activity within the human body. Microorganisms can generate many by-products through fermentation, which may even have commercial value and are easily produced. The cost/price margin is small because they can be easily replaced by cheap products and chemicals; however, they are naturally formed in the body. The development of non-dairy probiotic products is a major challenge in the food industry because many are lost during the processing and storage of the product. Cereals such as rice have been widely studied and can be used as fermentable substrates that favor the growth of probiotic microorganisms (Pomeroy et al. 2007b; Oliveira and Jurkiewicz 2009). Microorganisms have a high degree of specificity, acting separately in chemical reactions. Therefore, with the development of biotechnology, it could be possible to manufacture the food and perform transformations that can affect people's lives.

\section{ACKNOWLEDGMENTS}

The authors are grateful to the University of Vale do Rio dos Sinos/UNISINOS, the Institute for Science, Technology and Innovation in Food / NUTRIFOR and the Foundation for Research Support of Rio Grande do Sul/Fapergs. Special thanks to Lord Jesus for all $\mathrm{He}$ has done in our lives.

\section{REFERENCES}

Abrantes PM, Magalhães SMS, Acúrcio FA, Sakurai E. Quality assessment of antibiotic prescriptions dispensed at public health units in Belo Horizonte, Minas Gerais, Brazil, 2002. Cad Saúde Pública. 2007; 23(1): 95-104. DOI: 10.1590/S0102311X2007000100011

Andreote FD, Azevedo JL, Araújo WL. Assessing the diversity of bacterial communities associated with plants. Braz J Microbiol. 2009; 40: 417-432.

Andreoti FD, Azevedo JL, Araújo WL. Assessing the diversity of bacterial communities associated with plants. Braz J Microbiol. 2009; 40: 417-432. DOI: 10.1590/S1517-83822009000300001

Barbosa FHF, Martins FS, Barbosa LPJL, Nicoli JR. Microbiota indígena do trato gastrintestinal. Rev biol ciênc terra. 2010; 10: 78-93.
Bedani R, Rossi EA. Microbiota intestinal e probióticos: implicações sobre o câncer de cólon. $J$ port Gastrenterol. 2009; 15: 19-28.

Blaut M, Clavel T. Metabolic diversity of the intestinal microbiota: implications for health and disease. $J$ Nutr. 2007; 137: 751-755.

Boncowski M, Roy J. Soil microbial diversity and soil functioning affect competition among grasses in experimental microcosms. Oecologia 2005; 143: 232240.

Brandt KG, Sampaio MMSC, Miuki CJ. Importância da microbiota intestinal. Pediatria. 2006; 28(2): 117127.

Camargo PL, Uenaka SA, Motta MB, Adania CH, Yamasaki L, Alfieri AA. et al. Gastric helicobacter spp. infection in captive neotropical brazilian feline. Braz J Microbiol. 2011; 42: 290-297.

Clotildes MNM, Taddei JAAC, Diniz-Santos DR, May DS, Carneiro, NB, Silva LR. Incidence of diarrhea: poor parental recall ability brazilian journal of infectious diseases. Braz J Infect Dis. 2007; 11(6): 130-142.

Comte J, Jacquet S, Viboud S, Fontvieille D, Millery A, Paolini G. et al. Microbial community structure and dinamics in the largest natural French lake (Lake Bourget). Microb Ecol. 2006; 52: 72-89. DOI:10.1007/s00248-004-0230-4.

Coppens, PSM, Pettman S. European regulations on nutraceuticals, dietary supplements and functional foods: a framework based on safety. Toxicology. 2006; 221: 59-74.

Coutinho HLC, Oliveira VM, Manfio GP, Rosado AS. Evaluating the microbial diversity of soil samples: methodological innovations. An Acad Bras Ciênc. 1999; 71(3): 491-503.

Delzenne NM, Neyrinck AM, Cani PD. Modulation of the gut microbiota by nutrients with prebiotic properties: consequences for host health in the context of obesity and metabolicsyndrome. Microb Cell Fact. 2011; 10: 1-11. DOI: 10.1186/1475-285910-S1-S10.

Dickens HE, Anderson JM. Manipulation of soil microbial community structure in bong and forest soils using chloroform fumigation. In: Griffiths, BS. et al. An examination of the biodiversity-ecosystem function relationship in arable soil microbial communities. Soil boil Biochem. 2001; 33: 17131722.

Douglas-Escobar M, Elliott E, Neu J. Effect of Intestinal Microbial Ecology on the Developing Brain. JAMA Pediatr. 2013; 167(4): 374-379. DOI: 10.1001/jamapediatrics.2013.497.

Eussen SRBM, Verhagen H, Klungel OH, Garssen J, Henk HL, Kranen JV, Rompelberg CJM. Functional foods and dietary supplements: Products at the interface between pharma and nutrition. Eur $J$ Pharmacol. 2011; 668: 52-59. 
Griffiths BS, Ritz K, Wheatley R, Kuan HL, Boag B, Christensen $\mathrm{S}$. et al. An examination of the biodiversity-ecosystem function relationship in arable soil microbial communities. Soil Biol Biochem. 2011; 33: 1713-1722.

Hofman J, Bezchlebová J, Dušek L, Doležal L, Holoubek I, Ansorgová A. et al. Novel approach to monitoring of the soil biological quality. Environ Int. 2003; 28(8):771-778. DOI: $10.1016 / \mathrm{S} 0160$ 4120(02)00068-5.

Hunter-Cevera JC. The value of microbial diversity. Curr Opin Microbiol. 1998; 1(3): 278-85.

Instituto Brasileiro de Geografia e Estatística. Estatísticas do Brasil. [internet]. São Paulo (SP): Instituto de Pesquisa; 2013. [Updated 2013 Jul 7; cited 2013 Dec 09]. Avaliable from: http://www.ibge.gov.br/home/estatistica/populacao/c ondicaodevida/pof/2008_2009_composicao_nutricion al/tab_4.pdf

Johnson MJ, Lee KY, Scow KM. DNA fingerprint reveals links among agricultural crops, soil properties, and the composition of soil microbial communities. Geoderma. 2003; 114 (3/4): 279-303.

Kennedy AC. Bacterial diversity in agroecosystems. Agr Ecosyst Environ. 1999; 74 (1): 65-76.

Kirk MD, Little CL, Lem M, Fyfe M, Genobile D, Tan A. et al. An outbreak due to peanuts in their shell caused by Salmonella enterica serotypes Stanley and Newport-sharing molecular information to solve international outbreaks. Epidemiol Infect. 2004; 132(4): 571-577.

Kumar A, Henderson A, Forster GM, Goodyear AW,Weir TL, Leach JE. et al. Dietary rice bran promotes resistence to Salmonella enterica serover Typhimurium colonization in mice. BMC Microbiol. 2012; 12: 1-7. DOI:10.1186/1471-2180-12-71

Ley RE, Backhed F, Turnbaugh P, Lozupone CA, Knight RD, Gordon JI. Obesity alters gut microbial ecology. Proc Natl Acad Sci. 2005; 102(31): 1-7.

Maltick L, Rolon AS, Stenert C. Aquatic macrophytes in natural and managed wetlands of Rio Grande do Sul State, Southern Brazil. Acta Limnol Bras. 2010; 2: 133-146.

Ministério da Saúde. Agência Nacional de Vigilância Sanitária. Resolução RDC no 398, de 30 de abril de 1999. Regulamento Técnico que Estabelece as Diretrizes Básicas para Análise e Comprovação de Propriedades Funcionais e ou de Saúde Alegadas em Rotulagem de Alimentos. Diário Oficial da União [Internet]. maio 1999. Disponível em: http//www.anvisa.gov.br/legis/resol/449_99.htm

Moreira APB, Teixeira TFS, Peluzio GM, Alfenas CG. Gut microbiota and the development of obesity. Nutr Hosp. 2012; 27(5): 1408-1414. DOI:10.3305/nh.2012.27.5.5887.
Neyrinck AM, Delzenne NM. Potential interest of gut microbial changes induced by nondigestible carbohydrates of wheat in the management of obesity and related disorders. Curr Opin Clin Nutr Metab Care. 2010 Nov; 13(6): 722-728. DOI: 10.1097/MCO.0b013e32833ec3fb.

Odonkor ST, Ampofo JK. Escherichia coli as an indicator of bacteriological quality of water: an overview. Microbiol Res. 2013; 4(1): 1-7. DOI: 10.4081/mr.2013.e2.

Oliveira LB, Jurkiewicz CH. Influência de inulina e goma acácia na viabilidade de bactérias probióticas em leite fermentado simbiótico. Braz J Food Technol. 2009; 12(2): 138-144. DOI: 10.4260/BJFT20095808.

Paião FG, Arisitides LGA, Murates LS, Vilas-Bôas GT, Vilas-Boas LA, Shimokomaki M. Detection of Salmonella spp, Salmonella enteritidis and Typhimurium in naturally infected broiler chickens by a multiplex PCR-based assay. Braz J Microbiol. 2013; (1): 37-42.

Panizzon JP, Macedo VR, Machado V, Fiuza LM. Diversity of heterotrophic bacteria isolated from water in the paddy rice fields of southern Brazilian. $J$ Microbiol Res. 2012; 2(3): 60-67. DOI: 10.5923/j.microbiology.20120203.04

Panizzon JP, Macedo VR, Machado V, Fiuza LM. Microbiological and physical chemical water quality of the rice fields in Sinos River basin, Southern Brazil. Environ Monit Assess. 2013; 185(3): 27672775. DOI: $10.1007 / \mathrm{s} 10661-012-2747-1$

Pomeroy LR, Willians PJI, Azam E, Hobbie JE. The microbial loop. Oceanography. 2007b; 20: 28-33.

Pomeroy LR. The ocean's food web a changinging paradigm. Bioscience. 1974a; 24: 499-504.

Raizel R, Santini E, Kopper AM, Reis Filho ADR. Efeitos do consumo de probióticos, prebióticos e simbióticos para o organismo humano. Rev Ciência Saúde. 2011; 4(2): 66-74.

Reche MHLR, Fiuza LM. Bacterial diversity in ricefield water in Rio Grande do Sul. Braz J Microbiol. 2005; 36: 253-257.

Rodrigues FJ, Barroso AP. Etiologia e sensibilidade bacteriana em infecções do trato urinário. Ver Port Sau Pub. 2011; 2: 123-131.

Saad SMI. Probióticos e prebióticos: o estado da arte. Braz J Pharm Sci. 2006; 42(1): 1-14.

Santos LC, Cançado IAC. Probióticos e prebióticos: vale a pena incluí-los em nossa alimentação. FAPAM. 2009; (1): 308-317.

Santos TT, Varavallo MA. A importância de probióticos para o controle e/ou reestruturação da microbiota intestinal. Rev cient ITPAC. 2011; 4(1): 40-49.

Silva ZN, Cunha AS, Lins MC, Carneiro LAM, Almeida ACF, Queiroz MLP. Isolation and serological identification of enteropathogenic Escherichia coli in pasteurized milk in Brazil. Rev Saúde Pública. 2001; (4): 375-379. 
Tamura M, Hori S, Hoshi C, Nakagawa H. Effects of rice bran oil on the intestinal microbiota and metabolism of isoflavones in adult mice. Int $\mathrm{J} \mathrm{Mol}$ Sci. 2012;13: 10337-10349. DOI: 10.3390/ijms130810336.

Tiedje JM, Cho JC, Murray A, Treves D, Xia B, Ahou J. Soil teeming with life: new frontiers for soil science. In: Rees RM, Ball BC, Campebell CD, Watson CA. (Org.). Sustainable management of soil organic matter. Wallingford: $\mathrm{CAB}$ International. 2001; 5: 393-412.

Torsvik V, Ovreas L. Microbial diversity and function in soil: from genes to ecosystems. Curr Opin Microbiol. 2002; 5(3): 240-245.

Unicomb LE, Simmons G, Merritt T, Gregory J, Nicol $\mathrm{C}$, Jelfs $\mathrm{P}$ et al. Sesame seed products contaminated with Salmonella: three outbreaks associated with tahini. Epidemiol Infect. 2005; 133(6): 1065-1072. DOI:10.1017/S0950268805004085.
Vinholes DB, Assunção MCF, Neutzling MB. Frequência de hábitos saudáveis de alimentação medidos a partir dos 10 Passos da Alimentação Saudável do Ministério da Saúde. Pelotas, Rio Grande do Sul, Brasil. Cad Saúde Pública. 2009; 25(4): 791-799.

Yamanaka T, Helgeland L, Farstad IN, Fukushima H, Midtvedt T, Brandtzaeg P. Microbial colonization drives lymphocyte accumulation and differentiation in the follicle-associated epithelium of Peyer's patches. J Immunol. 2003; 170(2): 816-822.

Zeisel SH. Regulation of nutraceuticals. Science. 1999; 285: 1853-1855. 